\title{
Vývoj počtu účastníků a vhodnost počtu postupových míst na CrossFit Open 2011-2017
}

\section{Development of the participants' number and appropriateness of the number of qualifying places for CrossFit Open 2011-2017}

\author{
Michal Bozděch, Roman Kolínský, Jiří Zháněl
}

Fakulta sportovních studií, Masarykova univerzita, Brno

\begin{abstract}
Abstrakt
CrossFit je všestranně orientovaný tréninkový program zaměřený na rozvoj celkové kondiční připravenosti. Kzískání titulu „Fittest on Earth" musí účastníci projít tříkolovým eliminačním systémem (CrossFit Open, Regions, Games). Cílem studie je analýza vývoje počtu účastníků v letech 2011-2017 mužù $(n=1012297)$ a žen $(n=702$ 011) v prvním eliminačním kole a posouzení vhodnosti počtu postupových mist v jednotlivých regionech. Výzkumná data získaná z veřejně dostupných zdrojů prokázala vzrůstající lineární vývojový trend počtu účastníků $\left(R^{2}=0,98-0,99\right)$, počet mužũ byl v celém období vyšší oproti počtu žen. $V$ kategorii Individual Men (IM) bylv regionu Evropa v roce 2017 zaznamenán nejvyšší počet účastníků ( $n=40716 ;$ tj. 0,006\% z obyvatel regionu), nejmenší počet účastníků byl v roce 2017 zjištěn $v$ regionu Západní Kanada ( $n=3678, t j .0,028 \%$ z obyvatel regionu). V kategorii Individual Women (IW) byl v regionu Evropa v roce 2017 zaznamenán nejvyšší počet účastnic $(n=21742, t j .0,003 \%$ z obyvatel regionu), nejmenši počet účastnic byl zjištěn v regionu Západní Kanada $(n=3596$, tj. 0,027\% z obyvatel regionu). Nedostatek dobré shody počtu postupových míst byl v kategorii IM zjištěn v letech 2016 a 2017, v kategorii IW byla zjištěna dobrá shoda v celém sledovaném období 2011-2017. Test pomèru šancí prokázal, že v roce 2017 měli účastníci ze Západní Kanady 12,22krát větší šanci na postup než účastníci z Latinské Ameriky, zatímco účastnice ze stejných regionů měly 7,03krát větši šanci na postup. S ohledem na zjištěné výsledky lze pro kategorii IM doporučit úpravu počtu postupových mist a rozdělení regionu Evropa.
\end{abstract}

Klíčová slova: eliminační kola, regiony, vývojové trendy, tělesná zdatnost

\begin{abstract}
CrossFit is an all-round training program focused on the development of overall fitness. To win the title "Fittest on Earth", the participants must pass a 3-round elimination system (CrossFit Open, Regions, Games). The objective of the study is to analyze the development of participants' numbers in 2011-2017, men ( $n=1012297)$ and women $(n=702011)$, in $1^{\text {st }}$ elimination round and to assess the appropriateness of the number of qualifying places in particular regions. The research data from public sources show a growing linear evolutionary trend in the number of participants $\left(R^{2}=0.98-0.99\right)$; the number of men was higher than the number of women through the whole period. In the category Individual Men (IM), the highest number of participants ( $n=40716$; i.e. $0.006 \%$ of the region population) was registered in the region Europe in 2017; the lowest number of participants ( $n=3678$, i.e. $0.028 \%$ of the region population) was found in West Canada in 2017. In the category Individual Women (IW), the highest number of participants ( $n=21742$, i.e. $0.003 \%$ of the region population) was registered in Europe in 2017; the lowest number of participants ( $n=3596$, i.e. $0.027 \%$ ) was found in West Canada in 2017. The lack of good correspondence in the numbers of qualifying places was found in the IM category in 2016 and 2017; in the IW category, a good correspondence was found in the whole observed period 2011-2017. The odds ratio test has shown that in 2017, males from West Canada had 12.22 times bigger chance for qualifying than males from Latin America while females from the same regions had 7.03 times bigger
\end{abstract}


chance for qualifying. In view of the results, it is possible to recommend an adjustment of the number of qualifying places and the division of the region Europe.

Key words: elimination rounds, regions, evolutionary trends, physical fitness

\section{ÚVOD}

Ve většině sportů prováděných na vrcholové úrovni je nezbytným předpokladem $\mathrm{k}$ dosažení maximální úrovně faktorů (kondičních, taktických, technických atd.) důležitých pro konkrétní sportovní výkon. Tyto faktory bývají v odborné literatuře označovány jako faktory sportovně-specifické (Hohmann, 2009). Častým jevem je tzv. raná specializace, př̀ níž je trénink mladých sportovců zaměřen převážně na rozvoj těch faktorů, které determinují sportovní výkon v konkrétním sportu, a často je opomíjena všestranná příprava. To v sobě skrývá četná nebezpečí psychická (syndrom vyhoření, tzv. burn-out), zdravotní, motivační atd.

Protipólem tohoto př́stupu je CrossFit $(\mathrm{CF})$, všestranně orientovaný tréninkový program, který je zaměřen na rozvoj celkové kondiční připravenosti (general physical preparedness; GPP) a věnuje se mu stále více sportovců. Zakladatel CF programu Greg Glassman jej začal vyvíjet v 80. letech 20. století. Cílem bylo vytvořit tréninkový program zaměřený zejména na rozvoj celého komplexu motorických schopností (převážně kondičních) a dovedností (Janíčková, 2011; Leyland, 2012). V roce 1995 byla otevřena první tzv. CF tělocvična (CF Box, Santa Cruz, Kalifornia, USA), $\mathrm{v}$ dalších letech byla s rozvojem IT technologií zaregistrována internetová doména a vznikl elektronický časopis CrossFit Journal. CF program se stal postupně velmi populární, již v roce 2005 bylo jen v Santa Cruz celkem 18 tělocvičen CF Box, o 5 let později bylo již přibližně $1700 \mathrm{CF}$ Boxů po celém světě a v roce 2015 to bylo již přes 13000 , ve kterých denně cvičilo přibližně 2-4 mil. sportovců (Leyland, 2007; Wagner, 2010; Jančíková, 2011; Price, 2015). CF program je určitou formou tréninkových programů HIIT (high intensity interval training), resp. HIFT (high intensity functional training), které jsou podle autorů Poston et al. (2016) považovány za efektivní tréninkové programy pro zlepšení zdatnosti. Celková tělesná zdatnost je přitom důležitá jak v běžném životě, tak i v některých profesích, např. $v$ armádě, policii atd. $C F$ program je založen zejména na kombinaci anaerobního a silového tréninku, zaměřuje se na funkční pohyby př̀i současném zapojení více kloubů současně (Smith, Sommer, Starkoff, \& Devor, 2013). CF program je tedy relativně nový druh tréninku založený na vysoké intenzitě cvičení, různorodosti cviků a funkčních pohybech. Vysoká intenzita zatížení je dle některých autorů (Davies, Coleman, \& Stellino, 2016; Newton, 2017) dosahována především silovým tréninkem se zátěží (maximální, submaximální intenzity) nebo tréninku za pomoci váhy vlastního těla (při zachování relativně stejné intenzity zátěže, tedy počtu opakování, intervalů zátěže atd.). Prostor určený pro realizaci CF programu (CF Box) bývá vybaven hrazdami (dosažné, doskočné), činkami, vzpěračskými osami, bradly, gymnastickými kruhy, lany pro lezení, medicinbaly, veslovacími stroji, plyoboxy atd. CF program se postupně rozšíril z místa svého vzniku v USA do Evropy a dalších zemí, kde si získal oblibu a uznání (Weisenthal, Beck, Maloney, DeHaven, \& Giordano, 2014; Bellar, Hatchett, Judge, Breaux \& Marcus, 2015; Newton, 2017). Někteří autoři ovšem upozorňují, že vysoká variabilita CF cvičení a nedostatek kontroly během tréninku může způsobit problémy především méně zdatným a nezkušeným sportovcům (Weisenthal et al., 2014; Fernández-Fernández, Sabido-Solana, Moya, Sarabia, \& Moya, 2015; Davies et al., 2016). Mnoho zájemců provozuje CF program nejen pro zlepšení celkové kondice, ale také pro možnost navazovat sociální vazby, pro společné „rituální obětování lidské energie“ a pro pocit sebenaplnění (Mansfield, 2015). Pro CF program jsou charakteristická jednotlivá předem vytvořená cvičení (workouts of the day; WOD), která se nazývají 
např. dívčími či mužskými jmény, resp. jmény lidí, kteří zemřeli při výkonu služby (Glassman, 2011; Fernández-Fernández et al., 2015). Často i policejní a taktické složky či vojenské jednotky kontaktují lokální CF trenéry s žádostí o vytvoření cvičení (WOD), která by pomohla řešit problémy, se kterými se tyto organizace často setkávají při výkonu služby (Wallack, 2009; Svan, 2009). S CF programem je dnes obeznámeno veliké množství lidí, program se stává oblíbeným způsobem zvyšování kondice i v rámci tréninkové přípravy v různých (i olympijských) sportech (Bellar et al., 2015; Mullins, 2015). K intenzivnímu rozvoji CF programu také významně přispěla organizace soutěže CrossFit Games (CFG), jedné z nejprestižnějších soutěží v CrossFit komunitě. Systém soutěže umožňuje, že do prvního eliminačního kola CFG (Open) se může přihlásit kdokoliv, kdo splňuje základní požadavky (např. přiměřený věk a pohlaví pro zvolenou kategorii, zaplacení poplatku atd.). Účastník je povinen uvést, jestli je začátečník (tzv. Scales - sportovec, který zvládá pouze sníženou variantu náročnosti cvičení) nebo zkušený (tzv. Rx’d - sportovec vykoná předem danou sérii cviků bez modifikací). Začátečníci nemohou postoupit do dalšího eliminačního kola. Aby sportovec/kyně mohli získat titul „Fittest on Earth“, musí projít tř́íkolovým eliminačním systémem. Jednotlivá kola se nazývají Open, Regions a Games. Historicky první soutěž CF Games se konala v roce 2007 v Kalifornii (USA), v roce 2009 bylo přidáno kvalifikační předkolo a od roku 2011 musí účastníci projít dvěma eliminačními koly, než se dostanou na CF Games. K získání titulu „Fittest on Earth“v nejprestižnější kategorii Individual Men/Women je nutno nejprve projít prvním eliminačním kolem (Open) skládajícím se většinou z 5 WOD v 5 týdnech (jedná se o video účast). Druhé kolo (Regions) se skládá ze 7 předem vytvořených cvičení (WOD) v 3 dnech (osobní účast) a 3. kolo (Games) se skládá z 13-15 WOD v 4-5 dnech opět za osobní účasti (Tuthill, 2012). Finálového kola CF Games se může zúčastnit pouze 40 mužů a 40 žen kategorie Individual. $\mathrm{V}$ prvním eliminačním kole se sportovci $\mathrm{z}$ celého světa účastní soutěže v některém ze 17 regionů (z toho 10 v USA). Účast ve finálovém kole (CF Games) je finančně honorována. CF komunita často zdůrazňuje, že tzv. prize money jsou v CrossFit Games genderově korektní a počet mužů a žen pravidelně cvičících program CF je přibližně stejný (Rally Fitness, 2014). Kategorie Individual (Men/Women) je dlouhodobě nejpočetnější věkovou i výkonnostní kategorií na $\mathrm{CF}$ Open, o čemž svědčí i fakt, že její účastníci tvořili více než 80 \% z celkového počtu účastníků na CF Open 2017.

Z uvedené syntézy poznatků je zřejmé, že CrossFit program je dynamicky se rozvíjející, populární, ale v českých zemích poměrně málo známá forma rozvoje celkové kondiční zdatnosti.

Cílem našeho výzkumu byla analýza vývoje počtu účastníků v prvních eliminačních kolech (CF Open) v letech 2011-2017 a statistické zhodnocení, zda je počet postupových míst v regionech správně nastavený a jestli jejich účastníci mají stejnou šanci na postup v různých regionech.

S ohledem na syntézu poznatků a cíle výzkumu jsme formulovali následující výzkumné otázky:

1. Jaký byl vývoj počtu všech registrovaných účastníků na CrossFit Open v letech 2011-2017?

2. Jaký byl vývoj počtu účastníků v kategoriích Individual Men/Women v jednotlivých regionech?

3. Je poměr počtu postupových míst přiměřený $s$ ohledem na počet účastníků $v$ kategoriích Individual Men/Women v jednotlivých regionech?

4. Jaký je rozdíl v pravděpodobnosti postupu ve vybraných regionech v kategoriích Individual Men/Women?

\section{METODY}

Předložená studie analyzuje počet registrovaných účastníků v prvním eliminačním kole CrossFit Open v letech 2011-2017, celkem se jednalo o 1012297 mužů a 702011 žen. Výzkumná data byla získána z veřejně dostupných zdrojů (CrossFit Games, 2018; Statistics Canada, 2018; UNdata, 
2018), byla kategorizována podle zvolených výzkumných kritérií (pohlaví, rok, region, kategorie) a analyzována s využitím metod deskriptivní a analytické statistiky (absolutní a relativní četnosti, koeficient determinace). Pro posouzení shody teoretického (očekávaného) a empirického (pozorovaného) rozdělení četností dat výzkumného souboru byly s ohledem na velký rozsah výzkumných souborů použity testy chí-kvadrát $\left(\chi^{2}\right)$ a poměr šancí (Odds Ratio; OR). Teoretické rozdělení četností bylo stanoveno jako procentuální vyjádření počtu postupových míst $\mathrm{v}$ jednotlivých regionech $\mathrm{k}$ celkovému počtu postupových míst $\mathrm{v}$ jednotlivých letech, tyto četnosti byly vypočítány z celkového počtu 325 postupových míst v 17 oficiálních CF regionech. Teoretické četnosti tedy nabývaly hodnot 3krát 3,08\% (3× 10 míst), 1krát 4,62\% (1× 15 míst), 11 krát 6,15\% ( $11 \times 20$ míst), 2 krát 9,23\% ( $2 \times 30$ míst). Jako příklad pro výpočet poměru šancí na postup $(\mathrm{OR})$ byl jako region s největší pravděpodobností postupu zvolena Západní Kanada (Canada West, $n=3678$ mužů a $n=3596$ žen v roce 2017, 20 postupových míst) a jako region s nejmenší pravděpodobností na postup Latinská Amerika (Latina America, $n=22474$ mužů a $n=12648$ žen $\mathrm{v}$ roce 2017,10 postupových míst), a to s ohledem na poměr počtu účastníků v obou sledovaných kategoriích (Individual Men/Women).

\section{VÝSLEDKY}

Vývoj všech registrovaných účastníků na CrossFit Open 2011-2017

Na obrázku 1 je znázorněn vývoj počtu registrovaných účastníků CrossFit Open v letech 2011-2017 v kategoriích mužů, žen a všech účastníků dohromady.

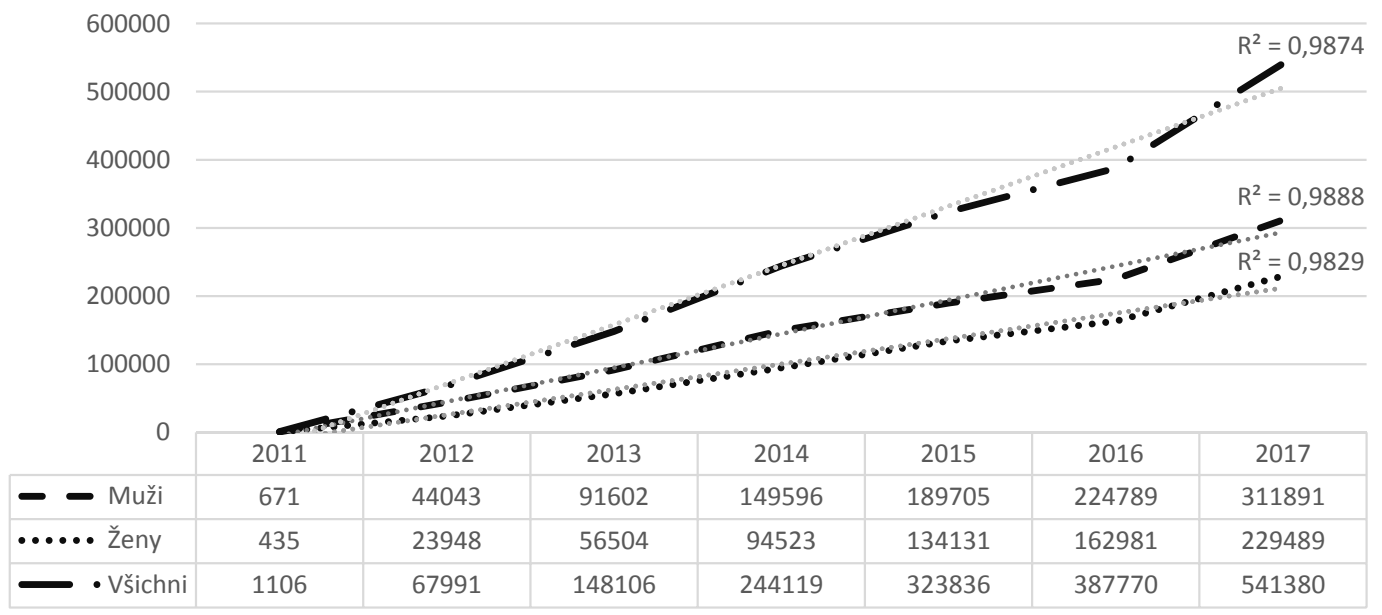

Obr. 1 Vývoj počtu všech registrovaných sportovců na CrossFit Open 2011-2017

Z obrázku 1 je jednoznačně patrný vzrůstající trend počtu účastníků soutěže CrossFit Open. Nárůst počtu účastníků CF Open má téměř lineární charakter. Shoda vývojových trendů s proloženou prrímkou byla posouzena pomocí koeficientů determinace $\left(\mathrm{R}^{2}\right)$. Je ve všech případech vysoká $\left(R^{2}=0,98-0,99\right)$, statisticky významná. Ve všech sledovaných letech převažuje počet mužů oproti ženám, nejnižší procentuální zastoupení žen $(35,2 \%)$ ve srovnání s počtem mužů $(64,8 \%)$ byl zjištěn v roce 2012, nejmenší rozdíl mezi procentuálním zastoupením žen $(42,4 \%)$ a mužů $(57,6 \%)$ byl v roce 2017. Jak vyplývá ze syntézy poznatků, byla vždy nejpočetněji zastoupena kategorie Individual (Men/Women), jejiž účastníci tvořili více než $80 \%$ z celkového počtu registrovaných 
sportovců. Z tohoto důvodů se v další analýze budeme zabývat pouze kategoriemi Individual Men a Individual Women.

\section{Vývoj počtu účastníků kategorie Individual Men v jednotlivých regionech}

Na obrázku 2 je znázorněn vývoj počtu účastníků v kategorii Individual Men v jednotlivých CrossFit regionech $(n=17)$ v letech 2011-2017.

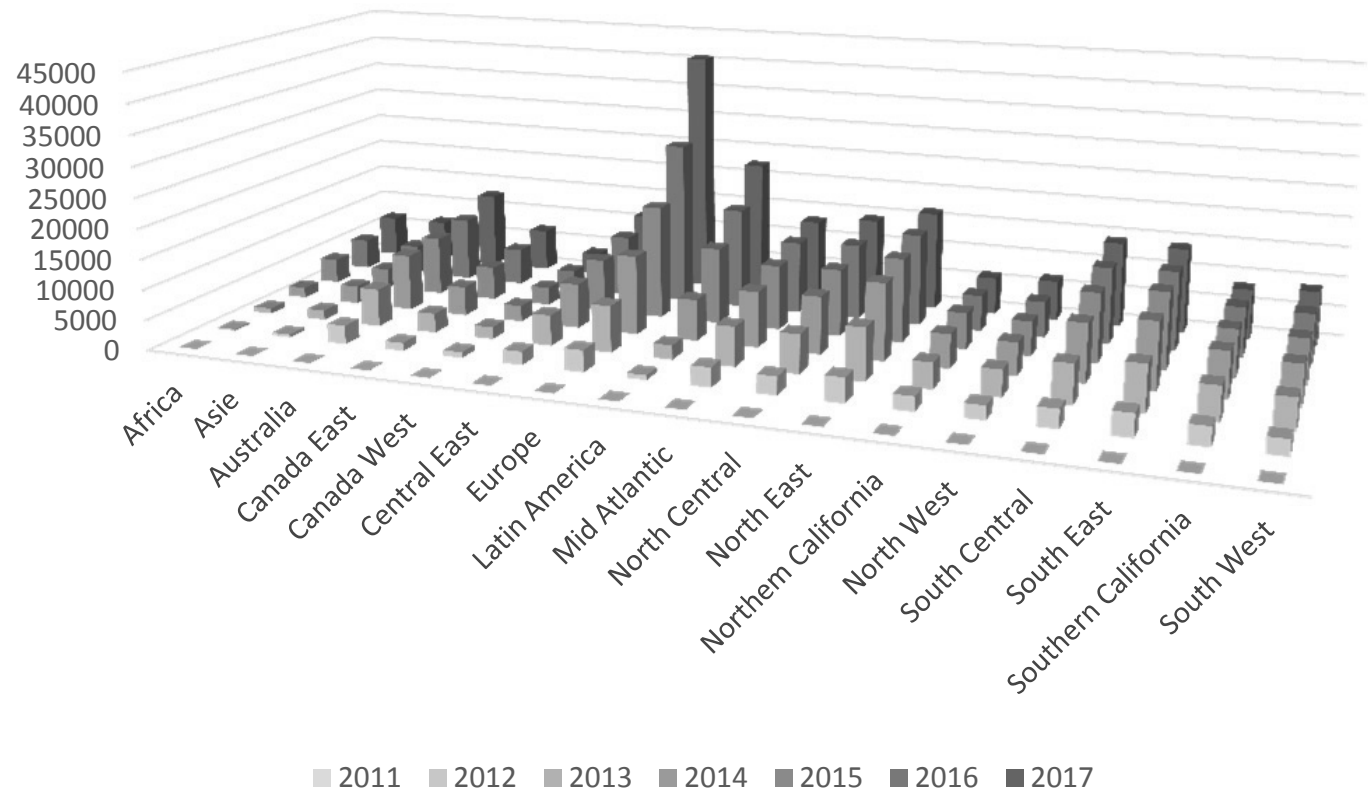

Obr. 2 Vývoj počtu účastníků v kategorii Individual Men podle CrossFit regionů

Z obrázku 2 je zřejmý postupný nárůst počtu sportovců ve všech regionech. K nejvýraznějšímu nárůstu došlo v regionu Evropa (Europe), a to z 50 účastníků (2011) na 40716 účastníků (2017), tedy 814 krát více. Výrazný nárůst počtu účastníků v Evropě se projevuje zejména od roku 2014 a je pochopitelně také ovlivněn potenciálem celkového počtu obyvatel. Rovněž v regionu Latinská Amerika došlo od roku 2011 ( $n=37)$ do roku 2017 ( $n=22$ 474) k výraznému navýšení počtu účastníků, a to zejména od roku 2014. V roce 2017 zde byl registrován druhý nejvyšší počet účastníků ( $n=22474$, tj. $0,004 \%$ z celkového počtu obyvatel). Naopak nejmenší nárůst počtu účastníků byl zjištěn v regionu Západní Kanada, který měl v roce 2011 jen 43 účastníků a v roce 2017 celkem 3678 , tedy 8553 krát více.

Pro lepší názornost ještě uvedeme procentuální zastoupení účastníků CF Open z celkového počtu obyvatel v některých regionech (data byla získána $\mathrm{z}$ veřejně dostupných zdrojů: Statistics Canada, 2018; UNdata, 2018). Regionem s největším počtem účastníků byla v roce 2017 Europa, počet účastníků CF Open $(n=40716)$ tvořil $0,006 \%$ z celkového počtu obyvatel. V regionu s nejnižším počtem účastníků (Západní Kanada, údaje o počtu obyvatel z roku 2016) tvořil jejich počet $0,028 \% \mathrm{z}$ celkového počtu obyvatel, tedy asi $4,7 \mathrm{krát}$ více než v regionu Evropa. V regionu Latinská Amerika tvořil počet účastníků $0,004 \%$ a v regionu Asie dokonce pouhých $0,0002 \%$ všech obyvatel. 


\section{Vhodnost počtu postupových míst $\mathbf{v}$ kategorii Individual Men}

Počet postupových míst $\mathrm{v}$ jednotlivých regionech je určen pořadateli a pohybuje se $\mathrm{v}$ rozmezí 10-30 postupových míst, konkrétně je to $\mathrm{v}$ jednotlivých regionech celkem $3 \times 10$ postupových míst, $1 \times 15$ míst, $11 \times 20$ míst a $2 \times 30$ míst (tyto údaje platí pro kategorie Individual Men i Women). Přidělený počet postupových míst vykazuje jisté nelogičnosti, např. region Latinská Amerika patří mezi regiony s největším počtem účastníků, přesto má pouze 10 postupových míst. Naopak region Západní Kanada má dlouhodobě nejnižší počet účastníků, ale přesto má dvojnásobný počet postupových míst (20) oproti regionu Latinská Amerika (obdobný stav je i v kategorii Individual Women). Statistické posouzení, zda teoretické rozdělení četností účastníků (poměr počtu postupových míst $\mathrm{v}$ jednotlivých regionech $\mathrm{k}$ jejich celkovému počtu) $\mathrm{v}$ jednotlivých letech se shoduje s empirickým rozdělením četností (počet registrovaných účastníků) v jednotlivých regionech, bylo provedeno pomocí chí-kvadrát testu $\left(\chi^{2}\right)$. Pomocí testu poměr šancí (Odds Ratio; OR) bylo dále zjištováno, jak veliká je pravděpodobnost postupu ve dvou vybraných regionech, tedy $\mathrm{v}$ regionu s nejmenším počtem postupových míst $\mathrm{v}$ poměru $\mathrm{k}$ počtu registrovaných účastníků (Latinská Amerika) a v regionu s největší počtem postupových míst v poměru $\mathrm{k}$ počtu registrovaných účastníků (Západní Kanada).

Tab. 1: Hodnoty výsledků testů $\chi^{2}$ a poměr šancí v kategorii Individual Men v jednotlivých letech

\begin{tabular}{|c|c|c|c|c|}
\hline Roky & $\chi^{2}$ & $\boldsymbol{p}$ & OR & CI \\
\hline 2011 & 4,80 & 1,00 & 1,72 & $0,87-3,42$ \\
\hline 2012 & 13,93 & 0,60 & 1,65 & $1,46-1,85$ \\
\hline 2013 & 11,52 & 0,78 & 2,37 & $2,20-2,56$ \\
\hline 2014 & 12,61 & 0,70 & 5,17 & $4,87-5,48$ \\
\hline 2015 & 19,68 & 0,23 & 8,52 & $8,08-8,98$ \\
\hline 2016 & 26,93 & 0,04 & 10,56 & $10,04-11,10$ \\
\hline 2017 & 38,51 & 0,00 & 12,22 & $11,67-12,79$ \\
\hline
\end{tabular}

Vysvětlivky: $\chi^{2}=$ chí-kvadrát test, $p=$ hladina významnosti, $\mathrm{OR}=$ poměr šancí (Odds Ratio), $\mathrm{CI}=$ interval spolehlivosti (confidence interval).

S ohledem na skutečnost, že vyšší hodnota chí-kvadrát testu vypovídá o větším nedostatku shody mezi očekávaným a pozorovaným rozložením četností, můžeme konstatovat, že největší nedostatek shody byl zjištěn v roce $2017\left(\chi^{2}=38,51\right)$ a nejmenší v roce $2011\left(\chi^{2}=4,80\right)$. Je zřejmé, že se zvyšujícím se počtem účastníků $v$ průběhu let 2011-2017 se snižovala přiměřenost počtu postupových míst v poměru k počtu registrovaných sportovců. Největší nedostatek dobré shody byl zjištěn v letech $2016(p=0,04)$ a $2017(p=0,00)$, lze tedy konstatovat, že zejména v těchto dvou letech není počet postupových míst $\mathrm{v}$ dobré shodě s počtem registrovaných účastníků.

Výsledky testu poměru šancí (OR, tabulka 1) ukazují, že např. v roce 2017 měl účastník z regionu Latinská Amerika 12,22krát menši šanci na postup do druhého eliminačního kola, než účastník z regionu Západní Kanada.

\section{Vývoj kategorie Individual Women v jednotlivých regionech}

Obdobně jako u obrázku 2 i následující obrázek 3 obsahuje vývoj počtu registrovaných účastnic v kategorii Individual Women (Rx’d) ve sledovaném období 2011-2017. 


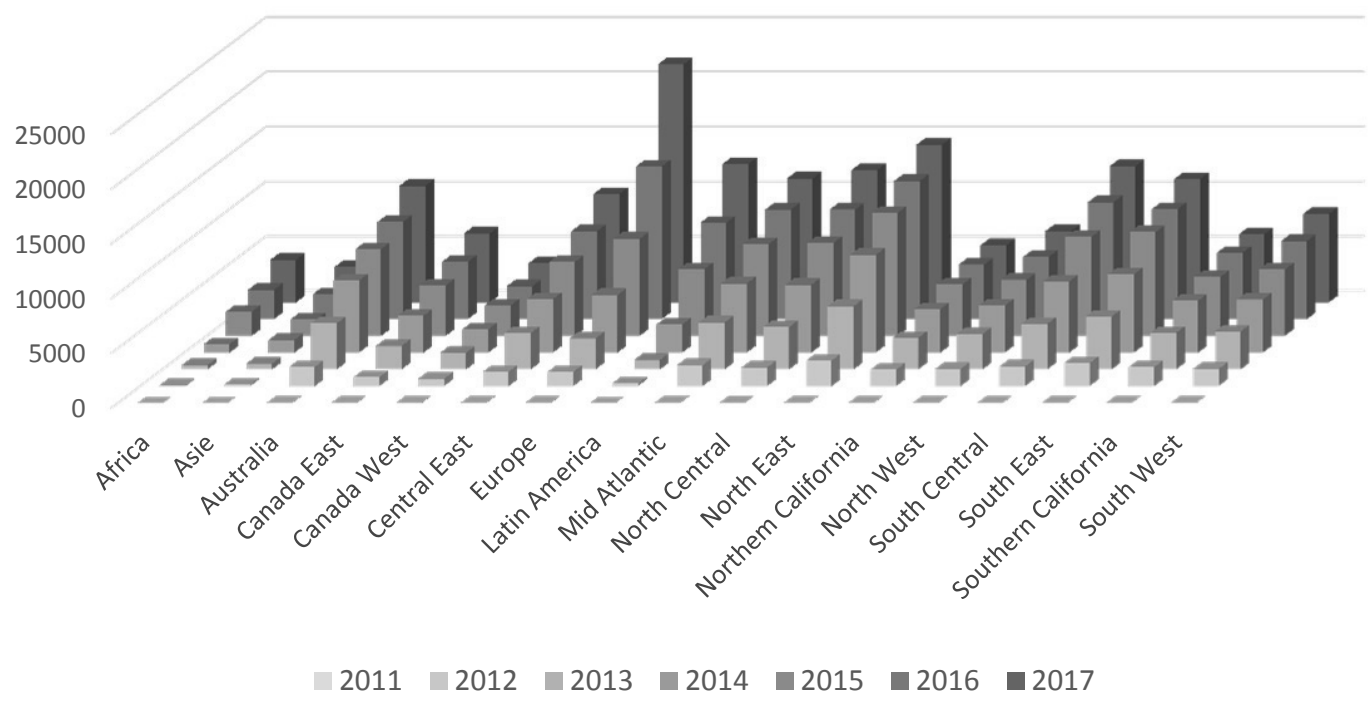

Obr. 3 Vývoj počtu účastnic v kategorii Individual Women podle CrossFit regionů

Z obrázku 3 je zřejmý nárůst počtu účastnic CF Open v jednotlivých regionech v průběhu let 2011-2017. K nejvýraznějšímu nárůstu došlo v regionu Evropa, a to z počtu 31 účastnic (2011) na 21742 účastnic (2017), tedy 701 krát více.

V letech 2012-2015 měl největši počet účastnic region Severovýchod (North East, $n=2$ 339-11 255), ale díky strmému nárůstu počtu účastnic se region Evropa od roku 2016 ( $n=13949)$ dostal na první místo v počtu účastnic. Naopak nejmenší nárůst účastnic můžeme vidět v regionu Západní Kanada, který měl v roce 2011 jen 27 účastnic a v roce 2017 celkem 3 596, tedy 133krát více. Trend největšího a nejmenšího počtu účastnic je shodný s trendem v kategorii Individual Men, který jsme popsali výše. Obdobně jako u kategorie Individual Men i zde jsme vypočítali procentuální zastoupení účastnic CF Open z počtu obyvatel ve vybraných regionech (data byla získána z veřejně dostupných zdrojü: Statistics Canada, 2018; UNdata, 2018) a zjistili jsme, že regionem s největším počtem účastnic v roce 2017 byla Evropa, počet účastnic CF Open $(n=21742)$ tvoří $0,003 \%$ z celkového počtu obyvatel Evropy. V regionu s nejnižším počtem účastníkủ (Západní Kanada, údaje o počtu obyvatel z roku 2016) tvoří jejich počet 0,027 \% z celkového počtu obyvatel, tedy 9 krát více než v regionu Evropa.

\section{Vhodnost počtu postupových míst v kategorii Individual Women}

Následující tabulka 2 použíá statistickou metodu chí-kvadrát test $\left(\chi^{2}\right)$ pro posouzení vhodnosti počtu postupových míst $\mathrm{v}$ jednotlivých regionech vzhledem $\mathrm{k}$ počtu účastnic $\mathrm{v}$ jednotlivých regionech. Dále statistickou metodu poměr šancí (Odds Ratio; OR) pro posouzení velikosti šance na postup z regionů s nejmenší a největší pravděpodobností na postup do dalšího eliminačního kola. 
Tab. 2: Hodnoty výsledků testů $\chi^{2}$ a poměr šancí v kategorii Individual Women v jednotlivých letech

\begin{tabular}{|c|c|c|c|c|}
\hline Roky & $\chi^{2}$ & $\boldsymbol{p}$ & OR & CI \\
\hline 2011 & 4,96 & 1,00 & 0,37 & $0,12-1,18$ \\
\hline 2012 & 17,12 & 0,38 & 0,75 & $0,63-0,89$ \\
\hline 2013 & 16,04 & 0,45 & 0,58 & $0,52-0,64$ \\
\hline 2014 & 13,42 & 0,64 & 2,41 & $2,23-2,60$ \\
\hline 2015 & 13,43 & 0,64 & 4,39 & $4,13-4,67$ \\
\hline 2016 & 15,18 & 0,51 & 5,87 & $5,55-6,21$ \\
\hline 2017 & 19,48 & 0,24 & 7,03 & $6,69-7,40$ \\
\hline
\end{tabular}

Vysvětlivky: viz tabulka 1

Výsledky posouzení významnosti rozdílu mezi očekávaným a empirickým rozložením dat pomocí $\chi^{2}$ testu prokázaly nevýznamné rozdíly v celém sledovaném období $(\mathrm{p}>0,05)$. Můžeme si všimnout, že hodnota poměru šancí (Odds Ratio; OR) každým rokem stoupá. Největší hodnota byla vypočítaná pro rok $2017(\mathrm{OR}=7,03) \mathrm{s}$ intervalem spolehlivosti 6,69 až 7,40. Tato hodnota uvádí, že účastnice regionu Západní Kanada měla v roce 2017 více než 7 krát větší šanci na postup do dalšího eliminačního kola než účastnice z regionu Latinská Amerika.

\section{DISKUSE}

Jak uvádí v přehledové studii Case (2017), mnoho výzkumů o historickém vývoji počtu mužských a ženských sportovců dokumentuje, že v řadě sportů počet mužů vysoce převyšoval a převyšuje počty žen. Jedním z důvodů může být i fakt, že dějiny ženského sportu začínají později, než tomu bylo u mužů, a to i z důvodu, že některé sporty byly považovány za nevhodné pro ženy (např. box, zápas). Z naší analýzy vývoje počtu účastníků soutěže CF Open v letech 2011-2017 vyplývá, že podíl žen se pohyboval mezi 35,2\% (2012) a 42,4\% (2017) s mediánem 39,3\% a zejména v posledních 3 letech se přibližoval počtu mužů (relativní zastoupení žen 2015: 41,42\%; 2016: 42,03\%; 2017: 42,39\%).

Při soutěžích CF Open mohou sportovci díky celosvětově zavedenému systému hodnocení výsledků srovnávat svoje výkony s výsledky nejlepších sportovců v regionu, kontinentu nebo na světě, což je stejné, jako kdybyste měli možnost srovnávat svoji tenisovou úroveň s úrovní tenistky Petry Kvitové (Edmonds, 2018). I tato skutečnost je zřejmě jedním z důvodů rostoucí popularity soutěži CF Open.

Z prezentovaných výsledků je zřejmé, že soutěže CF Open procházejí dynamickým vývojem, což potvrzuje předpoklad Price (2015), že CF „boom“ nevykazoval tendenci ke zpomalení a autorka očekávala v budoucnu další růst členské základny i počtu oficiálních CF Boxů. V souvislosti s nárůstem počtu účastníků organizátoři postupně rozšiřovali také počty soutěžních kategoriích. Zatímco v roce 2011 soutěžili účastníci pouze v kategoriích Individual Men/Women, v letech 2012-2013 to bylo již 5 kategorií, v roce 20146 kategorií, v letech 2015-2016 se počet kategorií rozšíríl na 8 a v roce 2017 na 9 kategorií. Současně se od roku 2015 všechny kategorie dělí na subkategorie Rx'd (zkušení sportovci) a Scales (začátečníci).

Výsledky předložené studie rovněž ukázaly, že pro spravedlivější postupový systém by měl být zejména region Evropa rozdělen na nejméně dva samostatné regiony, nebot z něj postupuje pouze $30+30$ mužů a žen. Při počtu 40716 registrovaných evropských účastníků v kategorii Individual Men a 21742 v kategorii Individual Women tedy např. v roce 2017 postoupilo pouze 0,074 \% mužů a $0,138 \%$ žen. To je relativně významně méně ve srovnání s regionem Asie $(10+10$ postupových 
míst pro obě kategorie), který patří mezi regiony s nejnižší účastí, kde postoupilo 0,145 \% mužů a $0,307 \%$ žen.

Analýza výzkumných dat ukázala, že poměr úspěšných uchazečů soutěže CF Open se v jednotlivých letech pohyboval v rozmezi $57-72 \%$ u souboru mužů a $59-73 \%$ u souboru žen. Nižší procentuální úspěšnost byla zjištěna v kategorii Individual, vyšší procentuální hodnoty pak převážně v kategorii Masters 60+.

Právo provádět úpravy počtu oblastí a počtu postupových míst mají pochopitelně pouze organizátoři soutěže CF Open. S ohledem na výsledky analýzy výzkumných dat si dovolujeme uvést několik návrhů možných úprav. Pokud by Evropa byla rozdělena na dva samostatné regiony, tak bychom navrhovali nový postupový systém skládající se ze 7 menších soutěží, které by se konaly v období prosinec-květen a z každé soutěže by postoupili 3 nejlepší účastníci a získali přímý postup do druhého eliminačního kola. Dále aby z CF Open postoupilo 15 nejlepších účastníků z každého regionu, 34 celosvětově nejlepších účastníků CF Open a výše uvedených 21 účastníků $\mathrm{z}$ průběžných soutěží. Tento systém by snižil stresový faktor $\mathrm{z}$ jedné velké soutěže, $\mathrm{s}$ tím spojené větší riziko zranění i výhody plynoucí $\mathrm{z}$ různého počtu postupových míst a podpořilo postup celosvětově nejlepších sportovců, i kdyby byli z jednoho regionu.

\section{ZÁVĚRY}

Analýza výzkumných dat prokázala vzrůstající trend počtu účastníků soutěže CrossFit Open v letech 2011-2017 v kategoriích mužů, žen i všech účastníků společně, byl prokázán lineární vývojový trend prostřednictvím koeficientu determinace. Počet zúčastněných mužů byl ve všech letech vyšší oproti počtu žen a pohyboval se mezi 35,2 \% a 42,4 \% s mediánem 39,3 \%, v posledních 3 letech je zřejmé vyrovnávání počtu mužů a žen. Dynamiku rozvoje zájmu o soutěž CF Open dokládá vzrůstající počet sportovců téměř ve všech regionech, a to v obou kategoriích (Individual Men/Women). V kategorii Individual Men došlo k nejvýraznějšímu nárůstu počtu zájemců v regionu Evropa, kde byl v roce 2017 zaznamenán absolutně nejvyšší počet účastníků. Nejmenši počet účastníků byl zjištěn v regionu Západní Kanada. V kategorii Individual Women došlo k nejvýraznějšímu nárůstu zájemců v regionu Evropa, v roce 2017 zde byl zaznamenán absolutně nejvyšší počet účastnic. Podobně jako v kategorii mužủ byl nejmenší nárůst a počet účastnic zjištěn v regionu Západní Kanada. Přiměřenost poměru počtu postupových míst s ohledem na počet účastníků byla ověrována pomocí chí-kvadrát testu $\left(\chi^{2}\right)$. V kategorii Individual Men byl zjištěn nedostatek dobré shody v letech 2016 a 2017. Lze tvrdit, že počet postupových míst $\mathrm{v}$ těchto letech není přiměřený počtu účastníků v jednotlivých regionech. V kategorii Individual Women jsme nezjistili nedostatek dobré shody mezi očekávaným a pozorovaným počtem účastníků v celém sledovaném období 2011-2017. Pomocí testu poměr šancí (OR) bylo prokázáno, že v roce 2017 měl účastník v kategorii Individual Men z regionu Západní Kanada 12,22krát větší šanci na postup, než účastník z regionu Latinská Amerika. V kategorii Individual Women (2017) měla účastnice z regionu Západní Kanada 7,03krát větší šanci na postup než účastnice z regionu Latinská Amerika. Přestože změnu podmínek soutěž CF Open mohou realizovat pouze pořadatelé, vzhledem k prokázanému nevhodnému počtu postupových míst v kategorii Individual Men lze doporučit úpravu počtu postupových míst a rozdělení regionu Evropa na minimálně dva samostatné regiony a zvážení nového postupového systému.

Autor prohlašuje, že tento článek nebyl jinde publikován ani současně nabídnut jinému periodiku, či vydavateli. 


\section{Reference}

Bellar, D., Hatchett, A., Judge, L. W., Breaux, M. E., \& Marcus, L. (2015). The relationship of aerobic capacity, anaerobic peak power and experience to performance in CrossFit exercise. Biology of Sport, 32(4), 315-320.

Case, M. A. (2017). Heterosexuality as a Factor in the Long History of Women's Sports. Law \& Contemporary Problems, 80(4), 25-46. Retrieved from http://ezproxy.muni.cz/login?url=https://search.ebscohost.com/login.aspx?direct=true\&AuthType=ip,cookie,uid\&db=a9h\&AN=128413377\&lang=cs\&site=eds-live\&scope=site

CrossFit Games. (2018). The Open. Retrieved from https://games.crossfit.com/open

Davies, M., Coleman, L., \& Stellino, M. (2016). The Relationship between Basic Psychological Need Satisfaction, Behavioral Regulation, and Participation in CrossFit. Journal of Sport Behavior, 39(3), 239-254.

Edmonds, W. (2018). Is the CrossFit Open the biggest sporting competition on Earth? CNN. Retrieved from https://edition. cnn.com/2018/02/19/sport/crossfit-open-biggest-competition-on-earth/index.html

Fernández-Fernández, J., Sabido-Solana, R., Moya, D., Sarabia, J. M., \& Moya, M. (2015). Acute physiological responses during Crossfit ${ }^{\circledR}$ workouts. Motricidad: European Journal of Human Movement.

Glassman, G. (2002a). The garage gym. CrossFit journal [online]. 9, 1-12. Retrieved from http://library.crossfit.com/free/ pdf/cfjissue1_Sep02.pdf

Glassman, G. (2002b). What is fitness?. CrossFit Journal [online]. 10, 1-11. Retrieved from http://library.crossfit.com/free/ pdf/CFJ_Trial_04_2012.pdf

Hammer, A. (2017a). 2017 CrossFit Games Rulebook Released. Floelite [online]. Retrieved from http://www.floelite.com/ article/50872-2017-crossfit-games-rulebook-released\#.WYv2wFFJZPZ

Hammer, A. (2017b). 2017 Reebok CrossFit Games Payouts: The Women. Floelite [online]. Retrieved from http://www.floelite. com/article/59970-2017-reebok-crossfit-games-payouts-the-women\#.WY_1OVFJZPY

Hohmann A. (2009). Entwicklung sportlicher Talente an Sportbetonten Schulen. Petersberg: Michael Imhof Verlag.

Jančíková, T. (2011). Crossfit (Bakalářská práce). Retrieved from https://is.muni.cz/th/343777/fsps_b/

Leyland, T. (2007). Why you should sprint train. CrossFit Journal [online], 57, 1-4. Retrieved from http://journal.crossfit. com/2007/05/why-you-should-sprint-train-by.tpl

Leyland, T. (2012). CrossFit and GPP. The Crossfit Journal, 9, 1-8. Retrieved from http://library.crossfit.com/free/pdf/CFJ_ GPP_Leyland_FINAL.pdf

Mansfield, E. (2015). Lessons can be learned from crossfit's popularity and marketing. O\&P Business News, 24(14), 56.

Marathon guide. (2018). Marathon results. Retrieved from http://www.marathonguide.com/results/browse.cfm?MIDD= 472171105

Mullins, N. (2015). CrossFit: Remember What You Have Learned; Apply What You Know. Journal of Exercise Physiology Online, 18(6), 32-44.

Newton, D. (2017). CrossFit. The Gale Encyclopaedia of Fitness [e-book]. Gale.

Poston, W. C., Haddock, C. K., Heinrich, K. M., Jahnke, S. A., Jitnarin, N., \& Batchelor, D. B. (2016). Is High-Intensity Functional Training (HIFT)/CrossFit Safe for Military Fitness Training? Military Medicine, 181(7), 627-637.

Price, K. (2015). No sign of CrossFit boom slowing down. Pittsburgh Tribune Review. Retrieved from http://www.iclubs.com/ more-news/no-sign-of-crossfit-boom-abating.html

Rishe, P. (2011). CrossFit's Relationship with Reebok Enhances Its Financial and Commercial Credibility. Forbes, 1-4. Retrieved from http://www.forbes.com/sites/sportsmoney/2011/07/22/crossfits-relationship-with-reebok-enhances-its-financialand-commercial-credibility/\#48637e2b3ab2

Smith, M. M., Sommer, A. J., Starkoff, B. E., \& Devor, S. T. (2013). Crossfit-based high-intensity power training improves maximal aerobic fitness and body composition. Journal of Strength \& Conditioning Research, 27(11), 3159-3172. doi: $10.1519 / \mathrm{JSC}$. 0b013e318289e59f

Statistics Canada. (2018). Canada at a Glace 2017 Population. Retrieved from https://www150.statcan.gc.ca/n1/pub/12-581-x/2017000/pop-eng.htm

Svan, J. (2009). CrossFit workout are rarely routine. Stars and Stripes [online]. Retrieved from http://www.stripes.com/news/ crossfit-workouts-are-rarely-routine-1.87018

Tuthill, M. (2012). Rich Froning is the fittest man alive. Joe Weider's Muscle \& Fitness, 73(12), 66-76.

UNdata (2018). World and Regional Profiles. Retrieved from http://data.un.org/Default.aspx

Wagner, J. (2010). Fitness as a Full-Time pursuit. The Wall Street Journal [online]. Retrieved from http://online.wsj.com/article/ SB10001424052748703837004575013350262520066.html?mod=WSJ_Small\%20Business_IndustryNews

Weisenthal, B. M., Beck, C. A., Maloney, M. D., Dehaven, K. E., \& Giordano, B. D. (2014). Injury Rate and Patterns Among CrossFit Athletes. Orthopaedic Journal of Sports Medicine, 2(4), doi:10.1177/2325967114531177

\section{Korespondující autor:}

Mgr. Michal Bozděch

Tel.: +420607 776709

E-mail: 360366@mail.muni.cz 